\title{
Why Distributive Justice Is Impossible but Contributive Justice Would Work
}

\begin{abstract}
PAUL GOMBERG*
ABSTRACT: Distributive justice, defined as justice in distribution of income and wealth, is impossible. Income and wealth are distributed either unequally or equally. If unequally, then those with less are unjustly subject to social contempt. But equal distribution is impossible because it is inconsistent with bargaining to advance our own good. Hence justice in distribution of income and wealth is impossible. More generally, societies where social relations are mediated by money are necessarily unjust, and Marx was wrong to think a socialist society which retained money would lead to communism. Contributive justice proposes that each flourishes by advancing the flourishing of others. To achieve this goal all labor, both simple and complex, must be shared among all capable of doing it. The good of contributing our abilities to benefit others is then available to all non-competitively.
\end{abstract}

\section{Introduction}

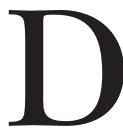

ISTRIBUTIVE JUSTICE, CONCEIVED AS just distribution of income and wealth, is impossible — for reasons to be explained. Social justice concerns how institutions affect people's lives for better or worse. When the quality of a person's life depends on access to money — on income and wealth — this

* Ancestor drafts of this paper benefitted from criticism from David Schmidtz, David Copp, and Serena Olsaretti. It was the subject of a colloquium at Indiana University/South Bend, where Mahesh Ananth acted as gracious host and made a decisive criticism; a colloquium of the American Philosophical Association, Pacific Division, in 2010, where Alastair Norcross was a helpful commentator; and a colloquium at the 2010 meeting of the Midwest Political Science Association, where Frank Lovett made several useful criticisms. More final drafts were given thorough and beneficial criticism from Russell Dale and Justin Holt of Science E् Society. 
dependence harms many people unjustly. While theories of distributive justice typically focus on income and wealth, contributive justice would create social conditions enabling all to live well and to earn respect for their social contributions; each flourishes by advancing the flourishing of others, or, in Marx and Engels' phrase from The Communist Manifesto, "the free development of each is the condition for the free development of all" (Marx and Engels, 1973, 87). I show how contributive justice is possible.

The leading proponent of the distributive paradigm, John Rawls (1999; 2001), combines market-based social relations (what he calls "property-owning democracy") with institutional structures intended to create egalitarian justice (fair equality of opportunity, broad dispersal of property and the powers consequent on property ownership). The present paper argues, from sociological and social psychological principles, that any possible money economy either leads to injustice or proposes something that makes no sense. The argument is not against Rawls alone (but I write with him in mind), nor is it conclusive; it should be plausible enough to get a hearing for contributive justice.

Income and wealth are central to justice, for Rawls and others, ${ }^{1}$ because they are all-purpose means by which people may advance their own conceptions of the good; in this way a conception of justice can be neutral between different conceptions of the good, neither promoting an ideal of life which constrains people's choices about how to live nor relying on controversial ideas of what makes life good. On this view a just society has a just distribution of income and wealth; each person's monetary resources allow her to live as she chooses.

However, a just distribution of income and wealth is impossible. Income and wealth will be distributed either unequally or equally. If wealth and income are unequal, those with less, I argue, suffer unjust harms. But, for reasons to be explained, an equal distribution cannot be sustained. Since equal distribution cannot be sustained and unequal distribution leads to unjust harms,

1 The others include Ronald Dworkin (1981; 2000), Richard Arneson (1989; 1999), G. A. Cohen $(1989 ; 2000 ; 2008 ; 2011)$, most participants in the equality versus priority debate, and capability theorists such as Amartya Sen $(1992 ; 1999 ; 2009)$ if they endorse market economies - as Sen does (1999, 111-46, especially 112). For the equality versus priority discussion see Clayton and Williams, 2002. 
distributive justice, understood as just distribution of income and wealth, is impossible.

The paper is organized as follows: section 2 considers the consequences of inequalities of income and wealth; section 3 explains why equal distribution of income and wealth cannot be sustained. In section 4 I summarize and explain how the argument defeats all conceptions of social justice that would allow money and markets; moreover, this argument is a criticism of Marx's "first phase of communist society" (Marx, 1974b, 347). Section 5 develops and defends a contributive conception of justice based not on what we receive but what we can contribute; contributive justice corresponds to the principle of contribution and distribution — "From each according to his abilities, to each according to his needs" - of Marx's "more advanced phase of communist society" (Marx, 1974b, 347). In section 6 I consider how we can get to a society of contributive justice from current capitalist injustice.

\section{Supposing Unequal Distribution of Income and Wealth:} The Rationalization Principle and Perceptions of Social Justice

Suppose income and wealth are distributed unequally. Money is an all-purpose means by which we advance our ends. Then for each of us it is a good in two senses: first, it enables us to reach certain goals; second, a consequence of the first, we regard it as good for us. So money is nearly universally thought of as a good. There may be exceptions. Some may believe it has pernicious effects. But even for them it is useful. The only conclusion I need for the rest of the argument is this: generally (if not universally) money is thought of as a good thing.

People tend to rationalize stable social institutions. Why would they do this? Possibly to reduce emotional dissonance. Stable social institutions tend to appear unchangeable. The thought that something is unjust sparks desire for change; the thought that an injustice will not change is depressing. To reduce the conflict between the desire for change and the thought that change will not occur, people tend to rationalize stable institutions, specifically to think them just. Let us call this tendency the Rationalization Principle. The speculation I have given of the origin of the Rationalization Principle may be incomplete; still, the principle names a tendency in all human societies: to the extent that they are stable and the 
possibility of social change becomes invisible, we rationalize our society by thinking it just. ${ }^{2}$

The Rationalization Principle should not be taken to imply that everyone thinks the social order just. It does imply, however, that assertions that a society is unjust are challenges to its continuing; if widely accepted, they tend to destabilize it.

2.1 Esteem for the Wealthy, Contempt for the Poor. The Rationalization Principle has further consequences. If money is an important good for each of us (even if only as a means) and if the social institutions in which it is a means are just, then people generally deserve the good things that they have. If some have more money than others, then they must be better in a relevant way (since the institutions are just and money is, for everyone, a good). I am not referring to the assertions of any theory: Rawls denies that in a just society people deserve their natural talents and advantages of birth and sometimes the material advantages they may have as a result of them; ${ }^{3}$ Hayek, Hume, and Rawls all argue against distribution according to merit or virtue (Hayek, 1984; Hume, 1975, 92-93; Rawls, 1999, 273-74). To think that people deserve what they have is a tendency in people's beliefs, an effect of rationalization: if those who have more good things are thought not to deserve them, then — to that extent - the society is thought to be less just than it might be. The belief that higher income and wealth are not earned through merit but result from luck or even injustice would be destabilizing. Obviously, if the Rationalization Principle correctly identifies a social tendency, stable societies tend to spawn conservative social thought.

Rationalization is a tendency; other tendencies reinforce rationalization or push our thinking in other directions. Specifically, we tend to defend our egos. People can believe (due to ego defense) that those above them in the hierarchy of wealth or income got there because they are lucky or unprincipled. Let me explain. If, due to my rationalizing wealth inequalities, I believe that those who have more wealth than I do deserve it and got it through greater intelligence

2 The idea of rationalizing what exists is entrenched in much Marxist literature as the source of ideology; see, for example, Fields, 1990, 106.

3 See Rawls, 1999, 89 on not deserving our talents; in pure procedural justice the outcomes of a just procedure are just, whatever they happen to be (74). So people are entitled to the material goods they have (but they may not deserve them - see 276 for the distinction between entitlement and desert and 273 and 276 for the distinction between moral desert and a non-moral sense of desert). 
than mine (smarter investments) or moral superiority to me (greater ability to restrain irrational impulses), then I diminish myself and undercut my self-esteem. Because we defend our egos, we are usually very reluctant to admit that those above us are superior to us. So ego defense may lead us to believe that those above us benefitted from advantages, were just lucky, or got to higher positions by being unscrupulous and unprincipled.

Those in economically superior positions tend to rationalize what exists by thinking that those below them are inferior. Rationalization and ego defense work in concert. Rationalization says that those with more wealth are superior in some way relevant to their having more, but this belief also inflates the egos of the wealthy. For members of the working class as well rationalization and ego defense may converge. When workers compare themselves to others who are worse off than themselves, they may experience a sense of superiority which rationalizes the system of inequality and enhances their egos.

Being further down in the hierarchy may cause us to regard more peoples' successes with suspicion. We may defend our egos and reject the idea that we are inferior.

But not all of us do; when rationalization subjects poor people to social contempt, some internalize this contempt, paying a price in lowered self-esteem. The Rationalization Principle explains why the poor are subject to contempt; research verifies that such feelings, often racialized, are often directed toward people who are worse off. ${ }^{4}$

Where there is inequality of income and wealth, there is a monetary hierarchy. The belief that people have what they deserve rationalizes this hierarchy. Those who have more think themselves superior to folks who have less. The former receive more social esteem, the latter less. We can observe the harms of rationalization in our society, as Michele Lamont's and Andrew Sayer's research shows. What I add here is that the same contempt for the poor that we can now see as

4 For evidence of both tendencies (looking down on those less well off and resenting those better off) see Sayer, 2005; Lamont, 2000, ch. 3.

The ways people perceive economic self-interest — this is different from ego-defense - can lead people to demean others perceived as competitors for important goods, people closer to their social position. Some antagonism within the working class, including racial antagonism, can be explained in this way. White workers have often felt threatened by struggles against racial injustice as they may fear falling from their own fragile position. Black workers may direct resentment more at white workers closer to their own social position than at capitalists. 
an effect of rationalization will exist in any money-based society as contempt for those who have less.

Granted, most of us value things other than money, and many disparage acquisitiveness and look down on "money-grubbers." Moreover, in societies with more compressed income and wealth differences both the physical and psycho-social harms to people lower down in the hierarchy may be less; I only insist that the harms would still be present and significant.

Rawls and especially Joshua Cohen try to defuse this problem by claiming that the status of equal citizenship would, in a just society, provide each with respect that would sustain our sense of self-worth (J. Cohen, 1997). However, this solution does not work. Let us suppose, with Rawls, that recognition of our status as a citizen provides equal and unconditional respect to each as a citizen. Nevertheless, it does not provide us with the respect we need. We need respect for our individual accomplishments, and - an effect of rationalization - our lower income and wealth operate as signs of inferior accomplishments and thus as a source of social contempt. Cohen also develops Rawls' argument that in a just society the difference principle (maximizing resources for people in the worst-off position) provides "the social bases of self-respect" to the least advantaged, because they are as well off as is possible, thus providing them with maximal resources to advance their own conception of the good and acknowledging their contributions to society. ${ }^{5}$ Still, their lower income and wealth operate as signs of inferior contributions.

In $§ \S 80-83$ Rawls addresses the "excusable envy" that could be a consequence of inequalities sanctioned by the difference principle. Excusable envy felt by the disadvantaged toward those more advantaged is grounded in visible disparities in income and wealth, which are likely to be much less in a just society than now. (Rawls calls these harms of social comparison envy. I believe that the pain is a response to the feelings of superiority of the advantaged and perhaps shame about one's own lesser position, feelings that are effects of rationalization.) Rawls adds that "the plurality of associations" makes the remaining

5 See J. Cohen, 1989; Rawls, 1999, 448. Rawls is explaining how those who were less well off would think about their own lesser opportunity even with equality of fair opportunity: "We are more ready to dwell on our good fortune now that these differences are made to work to our advantage, rather than to be downcast by how much better off we might have been had we had an equal chance along with others if only all social barriers had been removed." 
disparities less visible and hence less painful, dividing society "into so many non-comparing groups, the discrepancies between these divisions not attracting the kind of attention which unsettles the lives of those less well placed" (1999, 469-70).

This is certainly true now: social segregation, by race and also by class, reduces social contacts across both race and class and hence open displays of inequality which can spark feelings of shame in those less well off and superiority in the better off. But is this social segregation a good thing? Is it even tolerable? It represents our inability to create a human community, a world where all can be esteemed simultaneously by shared norms of esteem.

To understand the problems consider the segregation of the poor, particularly those who are racially stigmatized. Most social contacts are with others who are not distant from their own status position, that is, with people who are similarly poor. This segregation saves people the pain of frequent interactions with others who look down on them on account of their poverty. Yet the segregation has costs of its own. First, it locks people more deeply in their disadvantage by depriving them of skills and confidence that would help them either advance their interests (as, for example, in a job interview) or negotiate their interests with others above them; it can make people fearful of entering public spaces, even downtown streets, where they may be subject to contempt. Second, burying the pain of social comparisons does not eliminate the pain but puts it in a deeper place; whether they acknowledge it to others or even to themselves, poor people pay a big price in self-esteem when they are socially segregated, whether by economic or racial criteria. So whether they are socially segregated or share the same social space, those who are most disadvantaged are subject to social contempt.

To defeat this argument one could argue that it depends on the assumption that money can buy prestige but that in a just society just this sort of fungibility of money would be prevented; the norms which determine social esteem would be separate from the norms which determine how much money one gets (Walzer, 1983). However, a better understanding of how human societies rationalize inequalities shows that those with money will inevitably be thought better than the poor; money will be an important determinant of prestige.

2.2 Positionality Intensifies the Harm of Rationalization. I have argued so far that where societies are stable, inequalities in income and wealth 
tend to generate inequalities in social esteem, due to the effect of rationalization, and that inequalities in esteem harm those who have less. Because money is a source of esteem, it becomes not just an instrumental good but a positional good. A good is positional to the extent to which its value derives from its conveying rank relative to others (Hirsh, 1976). To the extent that X amount of money functions socially as a mark of position in the hierarchy of social esteem (an effect of rationalization) money becomes a positional good as does social esteem. Contests for positional goods are zero-sum: one person's gain is another's loss.

When the goods valued in a society are sought for their positional value, people do not become happier over time. Even as the society may become more affluent and people have more consumer goods, people's sense of well being does not improve. When people strive for status by trying to accumulate money and things or in other ways, things tend to go worse for them, and they suffer from more unhappiness, alienation, and depression. People whose values are focused on friendship and family do better psychologically. ${ }^{6}$

The negative effects of status rivalries are worth stressing. The more concerned we are with our status relative to others, the more jealous we become of others' accomplishments; it becomes harder to praise spontaneously others in a status similar to ours; it is harder to enjoy the accomplishments of even our friends. Others' accomplishments can seem a (relative) diminishment of our own. (Rousseau's discussion of amour propre is helpful here.) While this may seem a caricature of people's psychology (and it holds little truth about the psychology of people unconcerned with relative status), it captures the ways that rivalries can poison relationships.

Current theories of distributive justice advocate mediating human relationships through money and markets. But then money will function as a sign of worth, harming those with less. Positionality intensifies the harms done by rationalization. Positionality of wealth and esteem gives each an interest in diminishing the contributions and worth of

6 See Hirsh, 1976 and Layard, 2005 for evidence that greater social wealth does not lead to greater happiness. Tim Kasser's The High Price of Materialism (2002) reviews research showing the harmful psychological effects of materialism and status strivings and the better psychological profile of people whose values are oriented toward family and friends. Kasser's research is part of a large body of work on issues of motivation and flourishing under the paradigm of Self-Determination Theory, pioneered by Edward Deci and Richard Ryan at the University of Rochester (Ryan and Deci, 2000). 
those who are less well off, particularly those close to their own status position.

These arguments that a so-called "distributively just" society would lead to unjust harms are external in this sense: theories of distributive justice do not imply these harms as consequences of those theories apart from the psychological considerations I have raised. Rather, I am arguing that if such a "distributively just" society were to exist, then those with less money in that society would be harmed. The harms are the result of rationalization, which I have proposed as a psychological tendency in stable societies, but the Rationalization Principle is my principle and is external to those theories of distributive justice.

2.3 Socialization: Why Competition Cannot Be Fair. I have argued that inequalities in income and wealth harm those with less, but I have not shown that this is an injustice; if the harm results from choices for which those harmed may be rightly held responsible, it may not be an injustice. If, however, it results from socialization for inferior social positions, then it is an injustice. Specifically, economic and racial segregation of neighborhoods and schools (as well as different educational and social resources parents bring to childrearing) shape the aspirations and expectations of children from early in life, so that some children aspire to be architects and engineers while others aspire to be hair stylists and security guards. Moreover, children's abilities are socialized so that some are admitted to elite schools and others are not. For example, in a survey of 146 elite colleges it was found that only $3 \%$ of the students were from families in the bottom $25 \%$ in income and only $10 \%$ of students were from the bottom $50 \%$ in income (Carnevale and Rose, 2004). ${ }^{7}$ Hence the opportunity to attain economically advantaged positions is unequal, and the competition for them is unfair.

Some people must be socialized for inferior social positions. To explain this I need to introduce the Socialization Principle, which holds that children are socialized for available opportunities in numbers approximating those opportunities. No society will socialize many to do what only a few can do. The reason the Socialization Principle tends to be true is that socializing many to do what only a few can do frustrates ambitions; frustrated ambitions make people unhappy;

7 Wealth inequalities are much greater than income inequalities and often more greatly affect opportunities. See Conley, 1999. 
unhappy people will tend to cause trouble, destabilizing society. Socialization reduces competition and hence frustration by discouraging some from competing; it also gives some competitors an advantage. Thus the Socialization Principle identifies a tendency in stable societies to socialize people, particularly the young, for available opportunities in numbers that approximate the adult positions which will be available to them. ${ }^{8}$ It is a consequence of socialization, however, that competition cannot be fair, with each having an equal chance to succeed. Rather, some start with advantages; racial and class segregation of neighborhoods and schools — along with the sorting of students that occurs within schools - tends to socialize people to anticipate (and to acquire abilities suiting them for) different social positions. While equal competitive opportunity is advanced as an ideal, social practices needed for stability make that ideal unattainable.

We are assuming inequality of income and wealth; monetary inequality combined with rationalization has the consequence that those with greater income and wealth are more esteemed. We tend to aspire to the best life available to us. But the best lives are of limited availability. So we tend to compete for them. But competition can destabilize things. So the competition is rigged by socialization to exclude many from competing and make the residual competition unfair. This works through familiar racial and class injustices.

So far I have argued that two tendencies make distributive justice impossible: first, where income and wealth are distributed unequally, they are sources of unequal esteem, which is positional in a way harmful to those who have less; second, because of socialization, competition for advantage will not be fair. Hence those with less are unjustly harmed.

\section{Why Not Equality?}

There are two problems with equalizing income and wealth, one transitional and the other sociological. The transitional problem

8 How is the Socialization Principle related to the Rationalization Principle? They are separate social tendencies with different sources. The Rationalization Principle identifies a tendency in how we think about our society, a tendency which is a result of stability and hence the invisibility of any possible social change. In contrast, the Socialization Principle identifies a tendency in social organization to train people for positions only in numbers that approximate the numbers of positions that will be available to them. The source of the Socialization Principle is in the tendency of societies not to harbor social practices that would lead to social instability. 
derives from the positionality of both social esteem and wealth. Equalization would create positional winners and losers in equal numbers. Since those who had greater economic resources would be the losers, they could be expected to resist ferociously and to have greater power to make their resistance effective. In addition there are further problems in how people would perceive change from the point of view of their own responsibilities: as parents, the more advantaged see themselves as having a moral responsibility to convey advantage to their children. Equalization of wealth would deprive their children of a current advantage, and parents might conceive acquiescence with equalization as a betrayal of their parental responsibilities. Thus there would likely be formidable barriers to a transition from inequality to equality in income and wealth.

More important, a society with equal income and wealth makes no sense sociologically. We are assuming that money is an instrumental good; we use it to obtain things we need or want. Now suppose all agreed that no one should have more wealth than another, that they accepted what G. A. Cohen called an "egalitarian ethos." How would people participate in economic relations with others, in buying and selling or in negotiating compensation for labor? If money is an instrumental good, people would try to acquire more or spend what they have wisely. But, by hypothesis - if income and wealth are to remain equal - it is impossible to acquire more, and all agree that it should be impossible for one to acquire more than another. Are we to imagine that people try to do something even knowing it to be impossible? That makes no sense. As to spending one's money wisely: are we to acquire things as cheaply as possible? Should we shop at a Wal-Mart, where wages and prices are lower? Why would workers care about their wages, since income and wealth are to be equal? It is hard to know what one is to imagine in imagining a society where income and wealth are equal and all agree that they should be. ${ }^{9}$

Someone might reply that there would be a division of labor: while ordinary people try to acquire as much wealth as possible, the institutions of justice prevent inequality. But then the institutions will seem irrational and unjust to people judging them from the point

9 Carens, 1981 argues for a system where post-tax incomes are equal but people participate in market relations as income and wealth maximizers because pre-tax income is a mark of one's social contribution, and people are motivated morally to maximize social contribution. There are a number of problems with this proposal (Gomberg, 2007, 146-47). 
of view of their ordinary purposes and of the norms of social justice implicit in everyday economic relations (one is entitled to compensation negotiated in good faith). The appearance of irrationality is a result of retaining norms of economic relations which allow inequality (enrich oneself through fair bargaining) and combining them with social norms that are in contradiction with these. Because distributive equality will seem irrational, it is impossible to implement.

\section{The Problem Is Not Just Distributive Justice; It Is the Money Economy}

The problem with distributive justice is this: wishing to be neutral between controversial conceptions of what makes life good, philosophers propose money as a measure of who gets what. But money turns out not to be neutral in its effects. Money is distributed either equally or unequally. If unequally, money, being an all-purpose good, serves as a mark of social status, an effect of rationalization, leading to contempt for folks with less money; this contempt is intensified by positionality and status rivalry. Moreover, competition for status, due to socialization, will not be fair. I am not saying that any of this is what theorists such as Rawls intend - far from it. But the effects of making money a central instrumental good would defeat the egalitarian and non-competitive elements of their theories. If money is distributed equally, the resulting society would make no sense to people inside it.

The problem is the social relations in any society where money serves as a central means. Money-based societies create pernicious harms. So other conceptions of justice are vulnerable to the same arguments. A communitarian view of justice which retained a money economy would, in practice, lead to the same unjust harms I have explained here. And pluralist conceptions of justice, such as Michael Walzer's, also are undermined by the arguments here: in practice pluralism of norms gives way to the hegemony of money (Gomberg, 2007, 86-88).

Students of Karl Marx may also recognize a criticism here of what he called the "first phase of communist society" in Critique of the Gotha Programme (1974b, 347). This "first phase" has generally come to be called "socialism," a money economy where workers receive wages for their labor and exchange these wages for commodities. In Critique of the Gotha Programme Marx describes it as the worker contributing to society "his individual quantum of labor" and receiving back from 
this communist society a certificate representing this quantity of labor (minus deductions for goods that are communal and shared by all); that certificate can in turn be exchanged for goods from "the social supply of the means of consumption"; the amount of goods received represents the same quantity of labor as the quantity the worker has contributed through her labor. Marx recognizes that the principle at work is an exchange of equal values, that the workers' right to goods is "a bourgeois right," and that "this equal right still constantly suffers from a bourgeois limitation." He points out that workers are unequal in their abilities to work hard and produce and hence that an equal right is a right to inequality, that one will receive more for her labor than another. Of course, Marx thought that in a later phase of communist society (usually called "communism" simpliciter),

when the enslaving subjugation of individuals to the division of labour, and the antithesis between intellectual and physical labour has disappeared; when labour is no longer just a means of keeping alive but has become a vital need; when the all-round development of individuals has also increased their productive powers and all the springs of cooperative wealth flow more abundantly - only then can society wholly cross the narrow horizon of bourgeois right and inscribe on its banner: From each according to abilities, to each according to needs! (1974b, 347; also 346-47.)

The present paper challenges Marx's view of the transition from the first to the higher phase of communism: if revolutionaries build social relations that entrench bourgeois right and if (as I have argued would happen) these social relations are internalized and rationalized by individuals in socialist society, why think that the promised transition to communist society would occur? Wouldn't a return to fully capitalist society make more sense to people living in that socialist society (based on bourgeois right) than would a transition to a communist society based on a totally different conception of the purpose of labor, not to receive goods but to fulfill our humanity? Looked at in this light, the argument of the paper so far can be regarded as a partial account of why socialist revolutions in Russia, China, and elsewhere gave way to capitalism rather than to communism. ${ }^{10}$

10 While I am responsible for the development of the idea that socialism and communism are fundamentally contradictory ways of organizing society, the idea is not original with me. See Anonymous, 1982. 
The problem with Marx's account of the first phase of communism is the same as with theories of distributive justice and other conceptions that rely implicitly on money and market economies: money and markets imply their own principles of right and justice (and have their own sociological consequences, as I argued); as Marx recognized, the moral principle implied in market exchanges is bourgeois. The conception of justice implies that each should receive the equivalent of what she contributes to society and is grounded in a principle of equality. We labor to receive a just reward in exchange for our labor. Why should this notion give way to antithetical reasons why we should labor, not in exchange for rights to purchase consumer goods but because labor itself is a "vital need"? Here we find our good in advancing the good of others. We are not concerned with equality.

What dynamic in the first phase of communism would cause "the antithesis between intellectual and physical labor" to disappear? When Marx's prescription of two phases of communism was followed, it did not disappear nor did "the enslaving subjugation of individuals to the division of labour." No increase in the productive power of labor or in social wealth leads to distribution according to need and contribution according to ability. The norms governing the two proposed phases of communist society are radically opposed.

All of these considerations as well as the arguments of the first part of the present paper should lead us to suspect that no society founded on market exchange, wage labor, and bourgeois conceptions of equality and right would lead us to think of labor as a good. Yet Marx thought that in the right circumstances labor was a good. A contributive conception of justice starts, then, from the assumption that labor is a good, and asks what social organization could allow us to recognize it as such. We must show why each would realize a good life through social labor. I turn to that task in developing the idea of contributive justice.

\section{Contributive Justice}

Suppose, then, we start from assumptions in the tradition descended from Plato and Aristotle, particularly as it came to be recast by Marx: there is a human nature and a good for man. This good entails at least life as a social being and the development and exercise of human intelligence, particularly through labor that contributes 
to the social group. The term "labor" must be understood broadly enough to include a wide variety of human activities that we find valuable in one another, and "intelligence" broadly enough to include music, art, craft, social skill, and many other important exercises of complex ability. Through the development of these abilities and their exercise in a way that benefits ourselves and others, we come to think well of ourselves for our social contributions, and others think well of us for the same reason.

These, then, seem important goods: to develop our abilities, to exercise developed abilities in labor that contributes to human good, and to earn esteem for those contributions. These may be - I believe they are - uncontroversial enough that they could be accepted as goods that a just society should make available to all. That is, a theory of justice could start, not from purported neutrality about the nature of the good, but from a clear but widely acceptable account of what makes a human life good. ${ }^{11}$ From this point of view, the task of a theory of justice is to articulate social norms by which these important goods might be available to all. These are norms of contributive justice.

Under what social conditions would labor naturally be recognized as a good? In the Grundrisse Marx criticized Adam Smith's labor theory of value because it assumed that to labor was to sacrifice one's freedom and happiness. Smith found this assumption natural, Marx writes, because he was thinking of labor particularly as wage-labor where it "appears as repulsive, always as external forced labor." The subordination of the worker to the boss, where the worker must work in order to survive and must obey others in her labor, makes labor repulsive to the worker. Labor as self-realization requires that workers control the process of production, not be subordinated to it; they must exercise their will in deciding how production is to occur. We control our own labor often in work we do for ourselves, repairing our homes or cars, where we can make effective decisions and plan the labor process and carry out our own plan. Social labor can be controlled by the worker only when workers apply scientific knowledge to the labor process and decide collectively how it is to be organized (Marx, 1973, 610-12). When our labor is subordinated to a boss, it oppresses us; when we control our labor, it is a good.

11 The goods I have described here do not exhaust what is good but are important goods for all; see Gomberg, 2007, Chapter 6. Class societies make it impossible for all to obtain these goods simultaneously. 
There is a second social condition necessary to recognizing labor as a good. When some do relatively simple labor requiring little training while others carry out more complex tasks often requiring extensive prior training, inevitably a negative stigma attaches to the simple labor and the worker who does it. ${ }^{12}$ Labor can only be recognized as a good when this division of labor is overcome, when, because everyone does a share of the simple work, this labor no longer carries a negative stigma. Overcoming the division of simple from complex labor (essentially a restatement of what Marx called "the antithesis between intellectual and physical labor") requires that simple and complex labor be shared by all. When simple labor is shared no one's life is consumed with it. All have opportunity and social encouragement to develop more complex abilities with the expectation that they will be able to contribute these abilities to the good of others, once mastery is demonstrated. In mastering more complex abilities and contributing them we naturally earn esteem from ourselves and others. Similarly the contribution of simple labor also inspires esteem (once a negative stigma is removed from it) because those contributions enhance our lives.

Sharing simple and complex labor is necessary for the following reason: when labor is divided, greater esteem attaches naturally to the more complex labor. We feel an enhancement of self-esteem whenever we master a task which had previously been beyond our abilities. Teachers or entertainers who master complex difficult tasks naturally draw our admiration. So mastery of complexity naturally inspires esteem. No act of will can make us have the same admiration for contribution of simple labor that anyone can do as we have for the contribution of very difficult tasks that take years of intense training to master. Hence it does not make sense to suppose that, in a society where some do simple and others more complex labor, we will somehow will to esteem them equally. Moreover, in a society that divides simple and complex labor, those who do the simpler labor will be stigmatized as stupid because of the labor they do (an effect of the Rationalization Principle). But dividing labor also leads to socializing many for simpler labor (the Socialization Principle). In order to remove the stigma from

12 It is also true that simple labor is usually accompanied with closer supervision, while those who do more skilled labor are not closely supervised at all (think of the "supervision" of college teachers, which is very loose). So the second condition for recognizing labor as a good is related to the first: workers must be and recognize themselves as being self-governing. 
simple labor it must be shared by all. Therefore, justice requires that simple labor be shared. Similarly sharing complex labor is necessary in order to create social circumstances where each has opportunity to earn esteem from contribution of more complex mastery. Once labor-sharing removes the stigma attached to simple labor, we can enjoy the esteem that naturally attaches to doing necessary (even if simple) tasks as well as the esteem naturally attached to more complex contributions.

A society of contributive justice (one based on Marx's principle, "from each according to ability, to each according to need"13) would make normative the natural connection between contributing to society and esteem for those who contribute. Naturally we esteem those who contribute to a project with which we identify, and contributions to a society that we embrace as our own are hence naturally esteemed. Norms of contributive justice attach normative esteem to these contributions. Consider a parallel: We naturally regard parenting as a great good and naturally esteem ourselves and others who devote themselves to parenting. But we also consider it a parent's duty to care for and nurture the development of a child. We esteem those who do this because they are doing what they should do as parents; this is a normative connection between fulfilling the duties of parenting and being esteemed for doing those things. Norms of contributive justice make our contributions to society normative: members of a social group which supports them and cares for their needs should contribute to that group. So, while we naturally regard social contribution as a good and esteem those who contribute, we also have a duty to do so, and normative esteem attaches to those who fulfill this duty.

So contribution is both something that makes our lives good, that enables us to flourish, and also a duty of contributive justice. It may seem paradoxical that something is both a great good and a duty: if it is so good, why do we have to have norms making it a duty? The previous analogy to parenting should answer this question. Many of us who have raised children have found the experience of doing so a great - typically an irreplaceable - good in our lives. Yet parenting is a duty. Why? Because sometimes we don't feel like meeting the great demands in time and energy that parenting can place on us.

13 I say nothing here about what is a need; there is a brief discussion of this issue and other issues related to distribution in Gomberg, 2007, 162-63. 
It can easily take up a lot of time that we might rather spend doing something else. So it shouldn't be too surprising that we need norms to insure that the needs of our children are met - even though it is true that in meeting them we realize our own good. The same will be true of contributive duties: sometimes we just may not feel like getting up and doing our share of the necessary labor; we may feel like doing something else. So we need to recognize contribution as a duty even if it is a great good.

Both sides of this need to be explained further: why contribution is a good and why it is a duty. Let's start with why it is a good. Is it human nature to find our good through advancing the good of others? The research team led by Michael Tomasello has studied children for evidence of helping behavior, finding that children as young as 18 months tend to help others and will even interrupt their own activity to do so. Giving extrinsic rewards for helping tends to diminish their helping behavior (once the rewards are removed), evidence that they find helping intrinsically rewarding. Human children share much more readily than chimpanzees and display a sense of fairness which chimpanzees lack (Tomasello, 2009). Tomasello's research findings coincide with ethnographic studies of gatherer-hunter communities in contrast to chimpanzee communities: while humans organize food sharing through a camp, where hunted and gathered foods are brought back and shared according to norms, chimpanzees eat as they go, sharing only occasionally and reluctantly (even chimpanzee mothers are reluctant to share foods with their infants; their begging only gains them the inferior parts). We evolved in social groups where humans fed one another. ${ }^{14}$ It is deep in human nature for us to find our good in contributing to the good of others in the social life of a community.

We also need to understand why, in a society based on contributive justice, contribution to the good of others will readily be recognized as a duty. By the norms of contributive justice each cares for the good of others in familiar ways: providing food, transportation, building housing or public buildings, providing health care or other services. Each individual sees others providing for her. So it will make sense to her to do her part in this system; this is a duty of contributing and is easily recognized as such.

14 The literature on foragers is immense; but see Leacock and Lee, 1982, and the essays collected there. 
Let us now consider three possible problems with or objections to contributive justice. First, wouldn't competitiveness now characteristic of ambitious people persist? I believe not. Sharing labor makes opportunity unlimited. So we would naturally view others differently, not as competitors for limited goods (so that if you get into medical school, my chances are reduced) but as people whose developed abilities will enhance my life. Either you aspire to develop complex abilities in an area different from mine or in the same area. In the first case, your development of musical ability enriches my life just as my contribution of philosophy can enrich yours; our abilities are complementary. In the second case, your development of ability also enhances my life: I wish to write, think, and teach as well as possible; your development as a philosopher and philosophy teacher should enrich my life by surrounding me with others who can help me to do my work better just as I can help them. So in either case we have a natural reason to encourage others in the development of their abilities.

Second, what if everyone wants to do particle physics and no one wants to work on public health? Couldn't we have too many wanting to work in one area and not enough in another? Here I believe the natural desire to contribute should lead to people choosing to develop their abilities in areas where those abilities are needed. If the field of particle physics is crowded, the opportunity of each to make a contribution is somewhat diminished (although the work should be better because so many are collaborating on finding answers); if people are needed to work on public health, the opportunity to contribute is enhanced for people who enter the field. Assuming that each desires to contribute, we should naturally distribute the development of abilities to the areas where those abilities are needed.

Third, we should deal with the objection that even in a society based on contributive justice the problem of people being thought inferior will persist: after all, not everyone's contributions will be equal to those of others, and those who make the lesser contributions will naturally be thought inferior, by both themselves and others. I believe this objection imports a bourgeois way of thinking into a society of contributive justice. In capitalist society there is no shared sense of what is good. We tend to measure ourselves relative to others quantitatively, by income or wealth. There is positional competition. These are indeed characteristic of the social psychology of capitalist society. In sports, we value being number one. But this 
psychology is the result of our not sharing a sense of the intrinsic value of what we do.

In a society of contributive justice our contributions are genuinely valuable to others; they make their lives better. Of course, we are capable of comparing who did more and who did less, but the comparisons are not very important. Consider a comparison of John Rawls' A Theory of Justice with Eva Feder Kittay's Love's Labor. No doubt, if forced to rank them, we would agree that Rawls' is the greater contribution. But who cares? Kittay made an important criticism of the Rawlsian approach to justice, pointing out that dependency on others and doing the labor of caring for dependent people are central to our social experience and must be accounted for in any adequate theory of justice. I think Kittay's point is right and will lead to a better approach to social justice. It is an important contribution and one that leads others naturally to esteem what she has done and, I assume, leads her to feel proud of her contribution. It is simply not important that someone else made a greater contribution; each contribution has its own importance and hence should ground self-pride and social esteem. We seek the opportunity to contribute and make a difference to people's lives, and a society of contributive justice makes such an opportunity available to all simultaneously and non-competitively. So, I conclude, the problem of people being shamed by lesser contributions is not a real worry. We are not concerned to measure the quantity of social esteem. We are respected for contributions that are real and important.

In a society based on principles of contributive justice each is able to have a good life. Sharing labor, each does a fair share of the simple, routine labor according to ability; each has the opportunity and social encouragement to develop and contribute more complex abilities because this labor too is shared. Because our abilities tend to complement one another, each flourishes by enabling others to flourish; "the free development of each is the condition for the free development of all." Each develops a positive opinion of herself because of the esteem earned by contributing both simple and complex labor. Each has reason to accept the fundamental norms of contributive justice: that each contribute simple labor; that each develop her abilities; that each contribute developed abilities; that each share developed abilities by teaching others; that each encourage others in doing simple labor, developing more complex abilities, and contributing these; 
that each has the opportunity and encouragement to participate in social decision-making about how society is to be organized. While inevitably some will not be fully socialized to principles of contributive justice, will fail to contribute (or to contribute what they could), and will not win the esteem of others for their contributions, these should be at a minimum because of the social encouragement each would naturally receive.

Considering the good of contributing to a social group, the central problem of justice is how to make this good available to all simultaneously and non-competitively, to make this good available in unlimited supply. This problem has a solution, which is to share labor. Sharing the simple tasks has the consequence that no one's life is consumed with simple labor; each has opportunity and social support in the development and contribution of more complex abilities.

When contribution is the central good of concern to social justice, rivalry over goods which are marks of status disappears. When we become obsessed with the things money can buy for the social esteem they can win for us, we become less happy. This tendency arises at least partly from another: we don't love our work and feel confident that what we do has value in making life better for ourselves and others. In contrast, if labor is useful to others and we derive pleasure from it for that reason and for its intrinsic interest and challenge (assuming here that labor sharing gives everyone an opportunity to contribute more complex abilities to society), then we can find meaning and satisfaction in our lives. We can enjoy respect from others and from ourselves for something of genuine value. Contributive justice solves problems that distributive justice cannot.

\section{Getting There}

That leaves the question of how we get from capitalist society based on bourgeois conceptions of right and justice to the society of contributive justice based on the principle "from each according to ability, to each according to need." I argued earlier that the answer Marx proposed in the Critique of the Gotha Programme was wrong. But other things Marx wrote suggest a better answer. In The German Ideology Marx and Engels describe the workers' appropriation of the forces of production as "self-activity." In describing and analyzing the Paris Commune of 1871 Marx wrote that the communards "know that in 
order to work out their own emancipation ... they will have to pass through long struggles ... transforming circumstances and men." Marx describes how "plain working men ... performed their work [of governing Paris] modestly, conscientiously, and efficiently" and did so for modest wages (Marx and Engels, 1976, 87; Marx, 1974a, 213).

Admittedly the Commune did not abolish money. However, more to the point, the wages the communards received for governing this new working-class society — were these wages a compensation for their expenditure of effort? Or was their labor of "work [ing] out their own emancipation" a form of self-activity and self-realization? Were their wages merely the means of providing the necessities that would enable them to contribute? Marx never explicitly addressed this question, but it seems to me that he regarded the work of the communards as self-activity that did not require pay as a form of compensation but (since the commune had not abolished money) as a means of enabling them to do their work. If so, then their work and the pay they received were not based on "bourgeois right," including the right to inequality for those who did more work. Rather, revolutionaries carried out revolutionary activity for its own sake.

The same question - the same alternatives of working in order to make a living in bourgeois society versus working to build an anti-capitalist movement - exists for activists today. Some "activistentrepreneurs" see themselves as carving out a living for themselves and regard the money they earn as pay to which they are entitled. Others - more revolutionary in their thinking and way of living may receive subsistence pay in exchange for "working for the movement," but the pay is to provide for their needs so that they can do revolutionary work. When participants in the various Occupy movements performed the necessary work of providing food, organizing sanitation and cleaning up, and making sure that the medical or other special needs of their fellow occupiers were met, they were doing what they believed needed to be done, and they believed in that work. In their intercourse with the surrounding capitalist society, the occupiers needed money. But they typically did their work out of commitment, not for money.

Similarly, we can look at the movements that exist today to see whether the leaders think they are above performing the necessary menial tasks of tidying up or cleaning. Do they carry out in practice the 
unity of mental and manual labor (of complex and simple labor) to which the "higher phase of communism" aspires? Here again I am sure we see both practices among those who would label themselves "anticapitalist." However, my suggestion is that the movements that would overthrow capitalism must already carry out communist forms of life.

These communist practices within the anti-capitalist movement form the material basis for a society based on principles of contributive justice. In participating in these movements we find a form of self-realization. Those of us with other jobs certainly do not expect to be paid for our political activity; we participate out of commitment. So the material basis of a fully communist society is to be found in spreading that commitment as widely as possible. A decisive critical mass of the working class and its allies must participate in revolutionary anti-capitalist struggle out of commitment; that critical mass will then organize a new society based on principles of contributive justice. The political work they do in building this new society is not done to earn a paycheck but out of commitment. That same commitment can be extended to labor producing the necessities of life: if workers do not receive pay for working, then their motivation is political, to enable a new non-capitalist social order to succeed. But then they are already practicing the principle of Marx's higher phase of communism, working according to their abilities and commitment and receiving what they need in order to contribute (as everyone would, whether they worked or not). The struggle then is to persuade enough people to make this society work by doing the necessary productive labor. I have argued here that part of that process must also be to share simple labor, encourage all to develop other abilities, and share the contribution of these complex abilities as well; these practices prevent the working class from being divided into skilled, highly trained workers and others who do simple labor and are stigmatized thereby. Sharing labor enables all to experience self-realization through the contribution of labor. This is a society of contributive justice.

c/o Department of Philosophy

1240 Social Science and Humanities

University of California, Davis

Davis, CA 95616

pgomberg@earthlink.net 


\section{REFERENCES}

Anonymous. 1982. "Road to Revolution 4.” New York: Progressive Labor Party.

Arneson, Richard. 1989. "Equality and Equal Opportunity for Welfare." Philosophical Studies, 56, 77-93.

- 1999. "Equality of Opportunity for Welfare Defended and Recanted." Journal of Political Philosophy, 7, 488-97.

Carens, Joseph. 1981. Equality, Moral Incentives, and the Market. Chicago, Illinois: University of Chicago Press.

Carnevale, A. P., and S. J. Rose. 2004. "Socioeconomic Status, Race/Ethnicity, and Selective College Admissions.” In R. D. Kahlenberg, ed., America's Untapped Resource: Low-Income Students in Higher Education. New York: Century Foundation Press.

Clayton, Matthew, and Andrew Williams, eds. 2002. The Ideal of Equality. New York: Palgrave Macmillan.

Cohen, G. A. 1989. “On the Currency of Egalitarian Justice.” Ethics, 99:4, 906-44.

2000. If You're an Egalitarian, How Come You're So Rich? Cambridge, Massachusetts: Harvard University Press.

2008. Rescuing Justice and Equality. Cambridge, Massachusetts: Harvard University Press.

. 2011. On the Currency of Egalitarian Justice and Other Essays in Political Philosophy. Edited by Michael Otsuka. Princeton, New Jersey: Princeton University Press.

Cohen, Joshua. 1989. "Democratic Equality.” Ethics, 99:4, 727-751.

. 1997. "The Natural Goodness of Humanity." In Andrews Reath, Barbara Herman, and Christine Korsgaard, eds., Reclaiming the History of Ethics: Essays for John Rawls. Cambridge, England: Cambridge University Press.

Conley, Dalton. 1999. Being Black, Living in the Red. Berkeley, California: University of California Press.

Dworkin, Ronald. 1981. "What Is Equality?” Part 2: "Equality of Resources.” Philosophy and Public Affairs, 10, 283345. Reprinted as chapter 2 in Dworkin, 2000.

- 2000. Sovereign Virtue: The Theory and Practice of Equality. Cambridge, Massachusetts: Harvard University Press.

Fields, Barbara Jeanne. 1990. "Slavery, Race and Ideology in the United States of America.” New Left Review, 181, 95-118.

Gomberg, Paul. 2007. How to Make Opportunity Equal: Race and Contributive Justice. Oxford, England: Blackwell Publishing.

Hayek, Friedrich A. 1984. "Equality, Value, and Merit.” In Chiaki Nishiyama and Kurt R. Leube, eds., The Essence of Hayek. Stanford, California: Hoover Institution Press.

Hirsh, Fred. 1976. Social Limits to Growth. Cambridge, Massachusetts: Harvard University Press.

Hume, David. 1975 (1751). Enquiry Concerning the Principles of Morals. In David Hume, Enquiries. Third edition. Oxford, England: Clarendon.

Kasser, Tim. 2002. The High Price of Materialism. Cambridge, Massachusetts: MIT Press. Lamont, Michèle. 2000. The Dignity of Working Men: Morality and the Boundaries of Race, Class, and Immigration. New York: Russell Sage Foundation.

Layard, Richard. 2005. Happiness: Lessons from a New Science. New York: Penguin.

Leacock, Eleanor, and Richard Lee. 1982. "Introduction.” In Eleanor Leacock and 
Richared Lee, eds., Politics and History in Band Societies. Cambridge, England: Cambridge University Press.

Marx, Karl. 1973 (1858). Grundrisse. Harmondsworth, England: Penguin.

. 1974a (1871). "The Civil War in France" (Address to the General Council [of the First International]). In Marx, The Revolutions of 1848. Political Works, Vol. 1. David Fernbach, ed. Harmondsworth, England: Penguin.

- 1974b (1875). "Critique of the Gotha Programme.” In Marx, The Revolutions of 1848. Political Works, Vol. 1. David Fernbach, ed. Harmondsworth, England: Penguin.

1976 (1846). The German Ideology. In Karl Marx and Friedrich Engels, Collected Works, Volume 5. New York: International Publishers.

Marx, Karl, and Friedrich Engels. 1973 (1848). The Communist Manifesto. In Marx, The Revolutions of 1848. Political Works, Vol. 1. David Fernbach, ed. Harmondsworth, England: Penguin.

Rawls, John. 1999. A Theory of Justice. Revised edition. Cambridge, Massachusetts: Harvard University Press.

2001. Justice as Fairness: A Restatement. Edited by Erin Kelly. Cambridge, Massachusetts: Harvard University Press.

Ryan, Richard, and Edward Deci. 2000. "Self-Determination Theory and the Facilitation of Intrinsic Motivation, Social Development, and Well-Being." American Psychologist, 55, 68-78.

Sayer, Andrew. 2005. The Moral Significance of Class. Cambridge, England: Cambridge University Press.

Sen, Amartya. 1992. Inequality Reexamined. New York: Russell Sage Foundation. 1999. Development as Freedom. New York: Anchor Books. 2009. The Idea of Justice. Cambridge, Massachusetts: Harvard University Press.

Tomasello, Michael. 2009. Why We Cooperate. Cambridge, Massachusetts: MIT Press. Walzer, Michael. 1983. Spheres of Justice: A Defense of Pluralism and Equality. New York: Basic Books. 